\title{
THE INNOVATIVE APPROACH TO THE CRISIS SITUATIONS MONITORING OF THE SOCIAL AND ECONOMIC ORIGIN THAT ENDANGER THE SECURITY OF UKRAINE
}

\author{
Serhii Bielai' \\ Kyiv Faculty of the National Academy of the National Guard of Ukraine, Ukraine \\ Ihor Morozov ${ }^{2}$ \\ National Academy of the National Guard of Ukraine, Ukraine
}

Vyacheslav Tylchyk ${ }^{3}$

University of State Fiscal Service of Ukraine

\begin{abstract}
The purpose of the article is the explanation of innovative principles of the crisis situations monitoring of the social and economic origin that threaten the national security of Ukraine. The topicality of the crisis situations monitoring of the social and economic origin by the authorities that endanger the security of Ukraine is proved. The concept of "crisis situations monitoring" of the social and economic origin is defined. It is a system of monitoring, evaluating, and forecasting of social and economic threats to national security. Methodology. The crisis situations occurrence characteristics search on the Internet model allows searching the text files on the Internet with the help of the text files in order to evaluate the current situation, forecast the consequences of crisis situations of social and economic origin such as mass protest activism in regions of the country for further settlement. In view of this, the existing informative and analytical systems of the text information analysis systems are researched; the standard procedures of content analysis are investigated. The statistical analysis model is developed. In this regard, the list of significant indicators that determine the level of threats of social and economic origin and can lead to crisis situation consequences - the mass protest of public participation is formed. The threat level estimation model of the social and economic origin using modern theoretical and practical statistical methods and geographical information system methods is developed. The threat level forecasting model of the social and economic origin allows forecasting the crisis situation progress. With this end in view, the methods of the social crisis forecasting of social and economic origin are researched; the structured scheme of this mechanism is developed. Practical implications. The innovative approach to the crisis situations monitoring of the social and economic origin that endanger the security of Ukraine is developed. It is based on the usage of crisis situations occurrence characteristics search model, statistical analysis model, the threat level estimation and forecasting model of the social and economic origin. The themes for future research will be devoted to explanation and development of response mechanisms to the social crisis that threatens the national security of Ukraine.
\end{abstract}

Key words: crisis situations of social and economic origin, national security, monitoring, innovations, econometric and statistical methods, econometric modelling.

JEL Classification: C49, C50

\footnotetext{
Corresponding author:

${ }^{1}$ Faculty of Educational, Methodological and Scientific Affairs, Kyiv Faculty of the National Academy of the National Guard of Ukraine.

E-mail: Belwz3@ukr.net

${ }^{2}$ Department of Research and Organization, National Academy of the National Guard of Ukraine.

E-mail: Fozzy_i@ukr.net

${ }^{3}$ Department of Administrative Law and Procedure and Customs Security, University of State Fiscal Service of Ukraine.

E-mail: tilchikvv@ukr.net
} 


\section{Introduction}

Today Ukraine is a young European country that aspires to become a modern and developed social and legal state with a strong market-driven economy. Towards this end in view, the Government is developing and implementing reforms in the political, economic, social, scientific, technological, and other fields. However, the major obstacle for sustainable development is the modern threat to the national security that is reflected by increasing poverty rate, reducing level of the middle class, significant wealth disparity of the population, high level of government corruption and so on.

Currently, a special attention should be paid to the research of threats that have emerged on social and economic grounds. Present clearly demonstrates numerous crises of the social and economic origin. The economic crisis and its aftermath led to the recession of economic development and thus affected the extension of social problems and reduction of society standard of living and also the exacerbation of tensions in society. It is clearly demonstrated by the social and economic measures of Ukrainian regions.

The statistics of the most significant criminal offenses happened in 2013-2017 presented by the Prosecutor General's Office of Ukraine (Common reports of criminal offenses, 2017), confirmed the existing threats. The expansion in the number of reported crimes based on the main criteria of the "Crimes against national security" section, "Crimes against public safety" section, and "Crimes against public order and morality" section proves the likelihood of threats that are the repercussions of the crisis situations of the social and economic origin. Another group of criteria related to "Crimes in the area of performance and professional activities related to the provision of public services" section, "Crimes in the sphere of economic activity" section, and "Crimes against property" section characterize the existence of a crisis in the Ukrainian society most thoroughly.

Hence the existing management mechanisms are not able to deal with the abovementioned social and economic threats efficiently. Thus, it is urgent to research this question based on the theoretical and methodological foundations of the crisis situations monitoring of the social and economic origin that threat the national security of Ukraine.

The theme of human development, the vital state of being in society and living standards in society have been researched by such scientists as S.M. Ayusheyeva, B.D. Byelobrov, O.S. Dudolad, O.V.Zhadan, N.V. Ilchenko, A.I. Ilyash, D.V. Kolesnikov, V.O. Mandybura, O.A. Melnichenko, U.Y. Sadova, F.V. Uzunov, and others. The security aspect of living abilities under the situations of crisis events of the social and economic origin, social conflict and cooperation of public authorities and the population has been researched by such scientists as O.H. Afenkina, T.V. Biletska, S.I. Bilosorochka,
I.Y. Vorobyova, N.P. Dovgan, M.O. Kizim, K.I. Kozlov, M.M. Kononenko, T.A. Malyarenko, V.A. Mozharovskyi, O.V. Pankova, N.V. Stezhko, A.V. Stoyka, V.V. Uzunov, A.A. Haletska, O.V. Chernyavska and others.

The research of the monitoring issue of the crisis phenomena and the termination of the crisis situations with the huge protest participation of the population has been performed by such scientists and experts as Y.P. Babkov, A.V. Basov, V.M. Batsamut, V.Y. Bohdanovych, A.L. Vysidalkin, H.A. Drobakha, M.V. Korniyenko, S.O. Kuznichenko, V.Y. Lisitsin, M.M. Orlov, I.Y. Svyda, M.I. Skryhonyuk, O.O. Trush, O.M. Shmakov and others.

The scientists have studied the theoretical foundations of the crisis occurrence in social and economic systems; have presented the basic strategies regarding the estimation of the level of the society standard of living; have determined the ways for the reduction of the social tension level and for the social conflicts regulation; have covered the certain questions of crisis phenomena forecasting and regulation of the crisis situations etc. However, despite the wide range of research works about various aspects of crisis management of the social and economic origin, there is no complete mechanism of the social and economic threats' monitoring. Thus, this particular problem is urgent in present conditions of the social development.

The aim of the article is the explanation of innovative principles for the crisis situations monitoring of the social and economic origin that threaten the national security of Ukraine.

\section{Legal bases for crisis situations monitoring}

The main laws and regulations that declare the issue of national safety and security arrangements are: the Law of Ukraine "On National Security of Ukraine" (On National Security of Ukraine, 2018) and the National Security Strategy of Ukraine (The National Security Strategy, 2015). Further, let us consider the causes.

Article 7 of the Law of Ukraine "On National Security" identifies the threats to national security and the most urgent of them are: the lack of an effective financial crises prevention program; increase of credit risks; critical state of food supplies of the population; discrepancy of the reform programs of the national economy and the results of their implementation of certain social priorities; ineffective policies for improving the labour incomes, poverty reduction and balancing the productive employment of the working population; exacerbation of the demographic crisis; increase of the child and adolescent neglect, homelessness, vagrancy etc.

Article 8 of the Law of Ukraine "On National Security" defines the main directions of the state policy regarding the national security of the country's activity. Thus, the main directions are: laying the groundwork for sustainable economic growth; food supply security; 
the significant strengthening of the social dimension of the economic policy, the real increase of the living standards that will be primarily based on the increase in wages and early payment of wages and social benefits guaranteed bylaw, urgent strengthening target orientation of material support, reducing the unemployment; laying the conditions for poverty reduction and overcoming of the excessive social stratification; preservation and strengthening of demographic and labour resource potential; overcoming of the demographic crisis processes; elimination of homelessness, vagrancy and straying of children and adolescents.

Thus, it can be noted that the issue of the prevention and settlement of crisis situations of the social and economic origin that threat the national security of Ukraine in the Law of Ukraine "On National Security" has been determined quite clearly.

The National Security Strategy of Ukraine defines the direction of the government policy regarding the crisis response of the social and economic origin. The main challenging issues (determined in 3.4 chapter) that can threaten the security of Ukraine are: the economic crisis, the depletion of state financial resources, lowering of living standards; distorted governmental control and corrupt squeeze on business; mismanagement of national debt; reduction of the household wealth and rise in unemployment levels.

The basic directions of the state policy on national security of Ukraine have been determined in Section 4 of the National Security Strategy of Ukraine. The principal strategies for the effective security sector development and defence are: "centralized management of security and defence sector in peacetime, also in crisis situations that threaten national security and special period, interagency coordination and collaboration; ... improvement of the state strategic planning, development of the unique system of monitoring, analysis, forecasting, and decision-making in national security and defence sector, ensuring the effective coordination and functioning of the united system of situational centres of state relevant government bodies of the security and defence sector" (On National Security of Ukraine, 2018). The point of government policy is to implement the economic reforms, the basic content of which is to create conditions for overcoming poverty and excessive stratification in society, to approach the social standards to the level of Central and Eastern Europe countries the European Union, to achieve the economic criteria that are necessary for Ukraine to become a member of the European Union.

Thus, from the above reasoning, it should be mentioned that today the National security strategy of Ukraine determined the task for the state administrative body of the crisis phenomena monitoring. It comprises the development of the unique system of the monitoring, analysis, forecasting, and decision-making in the sphere of national security. The main threats that lead to the crisis situations of the social and economic origin are: high poverty rate, wealth disparity, social disparity, the absence of the vivid middle class.

\section{The structure of the innovative approach to crises situations monitoring}

According to the research of national security arrangement system, a special attention should be paid to the countermeasure of the controversial crisis phenomena repercussions of the social and economic origin. Here we provide such phenomena as violent civil disorders, rebellions, revolutions etc. These are the most dangerous phenomena and the main task of the monitoring is its early identification. The settlement of crisis situations that comprise social and economic component is the pressing issue of national security arrangements. Such phenomena ask to be treated as urgent and demand early effective management decision from the country's government. It is possible to avoid the social conflict in a society in case of the successful solution to a conflict situation. The escalation of the conflict leads to social crisis and it can be overcome in case of successful public policy and efficient administration of local self-government authorities.

If the problematic issues that cause the social and economic crises are not solved, the crisis will have the irreversible ruining character and lead to the social catastrophe.

In view of this, it is our opinion that the crisis situations monitoring of the social and economic origin is a system of monitoring, evaluating, and forecasting of social and economic threats to national safety.

During the development of this mechanism, it is appropriate to use innovative approaches. According to the Law of Ukraine "On Innovation Activity" (On innovation, 2012) we should understand newly-formed (implemented) and (or) improved competitive solutions, output and services and also organizational and technical questions of productive, administrative, commercial character and others that improve the structure and quality of production and (or) the social sphere considerably.

The innovative activity under section 3 of the Law of Ukraine "On Innovation Activity" involves:

- production and dissemination of new types of equipment and technologies;

- advanced cross-industry structural changes;

- implementation of the long-term scientific and technological programs with long terms of the return on investments;

- funding of fundamental studies for quality changes of the productive forces;

- development and introduction of new resourcesaving technologies in order to improve the social and environmental situation (Lavrova, 2012).

According to Y.V. Lavrova, the innovations are the eventual result of the innovative activity in the form of 
new or improved product or process with qualitative advantages while its usage, projection, production, sale and also it can be used for practical purposes and has a social advantage (Lavrova, 2012).

Therefore, on the assumption of the innovative principles, the methodology of socio-economic threat monitoring innovative approach should comprise three stages:

1) analysis, the development of the theoretical foundation;

2) the organizational aspect, the development of the methodological foundation;

3 ) test for adequacy in the social and economic system.

As follows from the research according to the mentioned methodology, the structure of the innovative approach to crisis situations monitoring of the social and economic origin that threaten the national security has been formed. The innovation consists in the geographic information system implementation as the platform of the monitoring. This platform has been used as the basis for the implementation of crisis situations occurrence characteristics search model.

The existing informative and analytical systems of the text information analysis systems have been researched in order to develop the crisis situations occurrence characteristics search on the Internet model (Figure $1)$; the standard procedures of content analysis have been investigated; the crisis situations occurrence characteristics search model with the help of text templates has been explained; the text templates on the principles of the calculation of content analysis standard procedures definitions that allow implementing the crisis situations occurrence characteristics search method of social and economic nature have been chosen.

The developed model allows searching the text files on the Internet with the help of the text files in order to evaluate the current situation, forecast the consequences of crisis situations of social and economic origin such as mass protest activism in regions of the country for further settlement. The sources for finding such information may include: text files in nets provided by media (periodical electronic publication); Internetpages of different sites that display operational news and announcements (especially regional and local); proper thematic blogs; social networks (Vkontakte, Odnoklassniki, Twitter, Facebook, etc.) that are considered to be additional means of obtaining the necessary information by authority of the competent bodies of state administration.

\section{Development of models for crisis situations monitoring}

The statistical analysis model has been developed. In this regard, the list of significant indicators that determine the level of threats of social and economic origin and can lead to consequences of crisis situations the mass protest of public participation - has been formed. The indicators are classified into groups: economic advancement (fixed investments, volume of export and import of services, volume of export and import of products); the consumer market and wages (the volume of retail trade turnover, average wages by regions, the index of actual wages, consumer price index, the arrears in wages); labour-market (the need for employees of enterprises, employment of unemployed citizens, the economic activity of the population, unemployed citizens in accordance (with the method of the International Labour Organization); demographic situation (the number of existing and permanent population, internal and external migration, births and deaths); crime (the total number of recorded crimes, the number of reported grave and especially grave crimes, crimes against public safety, crimes against public order and morals).

The mechanism of correlation and regression analysis of indicators of threats of social and economic origin with the consequences of the crisis situations (mass protest activity of the population) that allows forecasting the crises has been formed. It is established that the implementation of the mechanism of correlation and regression analysis is not always possible because of the probability of correlation dependences existence between the values of the mentioned indicators.

The threat level estimation model of the social and economic origin has been developed. It consists of four levels of the threats (lower, higher, high, and critical) and demonstrates the state security situation in this direction (Figure 1). It should be mentioned that each level of the threats may grade into another level and remain unaltered.

"Lower" threat level is characterized by the satisfactory level of the economic situation and social welfare in the country. This is a situation when public authorities and local governments perform tasks without complications.

"Higher" threat level corresponds to the occurrence of crisis situations of the social and economic origin. This is a situation when public authorities and local governments implement measures to restore the economy and social security.

"High" threat level corresponds to the occurrence of mass public protest activity, such as riots. This is a situation when state and local authorities implement measures to restore the economy and social security.

"Critical" threat level corresponds to the occurrence of conditions of the social disaster and imposition of the emergency administrative and legal regimes. This is a situation when the public authorities impose the emergency legal and administrative regimes.

It has been used the taxonomic method (Plyuta, 1989) to evaluate the levels of threats that allow analysing the diverse criteria. According to the algorithm of the taxonomic method, it has been suggested to use real past crisis situations in society that led to social disaster as the reference point. 


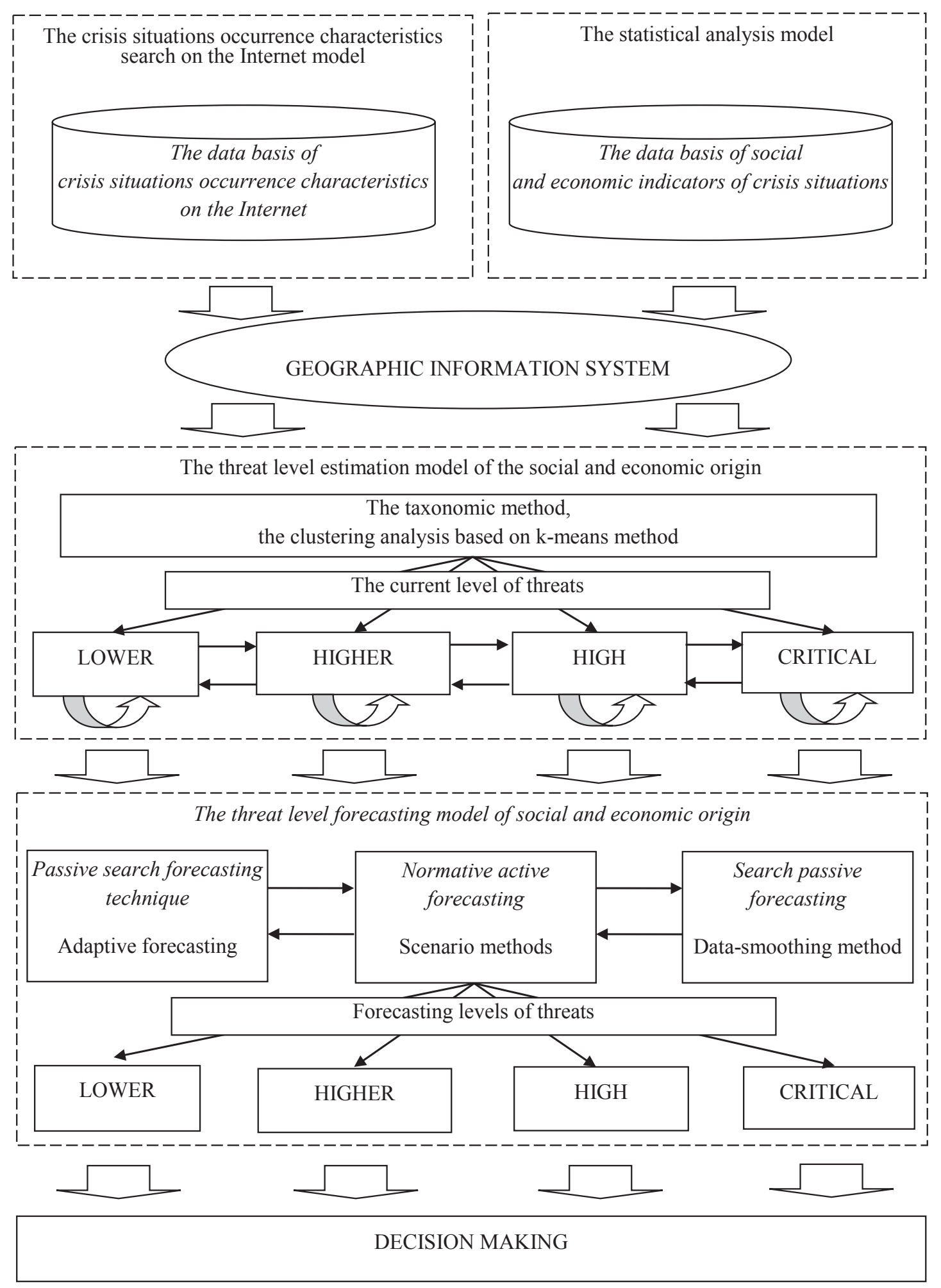

Figure 1. The structure of the innovative approach to crises situations monitoring of the social and economic origin that threaten the national security

The classical method of k-means clustering has been analysed. This method has explained significant issues regarding the use of this method in the estimation mechanism of crisis situations of social and economic origin.
Consequently, the modified method of k-means clustering analysis has been developed (Bielai, Lisitsyn, 2014). It combines the taxonomic method and the method of k-means clustering that allows analysing and forecasting the current crisis situations. 
The threat level forecasting model of the social and economic origin has been formed. It consists of active regulation (scenario method) (Novikov, Chhartishvili, 2002) and passive search (data-smoothing method, adaptive forecasting) forecasting techniques (Klebanovoy, Kizima, 2010).

The time series smoothing method allows to predict the emergence of a crisis with a long-term view (two years or more) using the moving average method and for a short term (within one period) by using exponential smoothing. The adaptive forecasting models have certain advantages as they are used in processes that do not always have fixed regularities-trends; adapt its structure and parameters quickly to modification of terms; take into account the time series levels' non-equivalence data discounting mechanism. Consequently, the adaptive forecasting models have been selected for the research, such as basic Brown model. This model represents the process of development as a linear trend with variable data. In order to predict the consequences of crisis situations of social and economic origin such as mass protest activity rate, it has been used scenario modelling search active forecast, which will help to develop a list of most probable (typical) scenarios of crises that may occur in the Ukrainian society. It has been suggested to use the reflexive control to develop the scenarios of crisis situations.

Now, therefore, the structured scheme of the threat level forecasting model of the social and economic origin has been developed.

Thus, the innovative approach to the crisis situations monitoring of the social and economic origin that threaten the security of Ukraine is based on the classical statistical analysis and forecasting methods combined with modern technologies of collecting, analysing, and plotting of spatial data on the electronic map with the help of technologies of the geographic information system.

Such an approach allows collecting the information, evaluating and forecasting the crisis situations in regions of the country. The mentioned innovative approach has been also reduced to practice with the help of the proper programming module.

\section{Conclusions}

1. The central task of the national security arrangement is the response to the crisis situation of social and economic origin. Such phenomena require timely and effective management decisions from country's governments. The main task of monitoring is to forejudge the crisis situations in advance. The monitoring of crisis situations of social and economic origin is a system of monitoring, evaluating, and forecasting of social and economic threats to national security.

2. The crisis situations occurrence characteristics search on the Internet model has been developed. It has been elaborated on the basis of definition of thematic text templates that describe the appearance of crisis situations in society and allows searching the text files on the Internet with the help of the text files in order to evaluate the current situation, forecasting the consequences of crisis situations of social and economic origin such as mass protest activism in regions of the country for its further settlement.

In view of this, the existing informative and analytical systems of the text information analysis systems have been researched. Thus, the crisis situations occurrence characteristics search on the Internet model (Figure 1) has been developed; the standard procedures of content analysis have been investigated; the classified table of the text templates choice has been formed; the crisis situations occurrence characteristics search model has been explained; the factors that characterize the crisis situations with the mass protest activity of population have been classified.

3. The threat level estimation model of the social and economic origin using modern theoretical and practical statistical methods and geographical information system methods have been developed; the indicators of the crisis situations of the social and economic origin that determine the level of socioeconomic threats to national security and may lead to the crisis situations with the mass participation of population have been explained; the modification of $\mathrm{k}$-means clustering method by applying and explaining four clusters i.e. the levels of threats that allow to subsume the crisis situation to the certain stage of the social situation in the region and forecast the situation primarily has been performed.

4. The threat level forecasting model of the social and economic origin that allows forecasting the crisis situation development has been formed. With this end in view, the methods of the social crisis forecasting of social and economic origin have been researched; the search active forecasting methods implementation i.e. the data-smoothing method have been explained. It allows to predict the occurrence of a crisis with a longterm view (two years or more) using the moving average method and for a short term (within one period) by using exponential smoothing and also linear adaptive forecasting models that are used in processes that do not always have fixed regularities-trends, adapt its structure and parameters quickly to the modification of terms; and take into account the time series levels' non-equivalence; the implementation of normative active forecasting i.e. scenario modelling method that allows developing a list of most probable (typical) scenarios of crises that may occur in society has been proved.

5. Themes for future research will be devoted to explanation and development of response mechanisms to the social crisis that threatens the national security of Ukraine. 


\section{References:}

Bielai S.V., Lisitsyn V.E. (2014). Vykorystannia modyfikovanoho metodu k-serednikh klasternoho analizu u zadachakh derzhavnoho upravlinnia $\mathrm{z}$ prohnozu kryzovykh yavyshch sotsialno-ekonomichnoho kharakteru [A modified version of the method of $\mathrm{k}$-average cluster analysis in the tasks of state control in predicting the crises of crises in a socially-economical manner]. Actual problems of public administration, vol. 4, no 60, pp. $211-214$.

Klebanovoy T.S., Kizima N.A. (2010). Modeli otsenki, analiza i prognozirovaniya sotsialno-ekonomicheskih system [Models of evaluation, analysis and forecasting of socio-economic systems]. Kharkov: PH «INZHEK». (in Ukrainian)

Lavrova Yu.V. (2012). Ekonomika pidpryiemstva ta marketynh [Business Economics and Marketing]. Kharkov: HNARU. (in Ukrainian)

Novikov D.A., Chhartishvili A.G. (2002). Aktivnyiy prognoz [Active forecast]. Moscow: ICS RAC. (in Russian)

Plyuta V. (1989). Sravnitelnyiy mnogomernyiy analiz v ekonomicheskom modelirovanii [Comparative multidimensional analysis in economic modeling]. Moscow: Finance and Statistics. (in Russian)

Ukaz Prezydenta Ukrainy vid 26.05.2015 r. № 287/2015 «Pro Stratehiiu natsionalnoi bezpeky Ukrainy» [Decree of the President of Ukraine 26.05.2015 № 287/2015 «On the Strategy of National Security of Ukraine»]. Retrieved from: http://zakon5.rada.gov.ua/laws/show/287/2015 (accessed 10 June 2018)

Yedyni zvity pro kryminalni pravoporushennia za 2013-2017 rr.: Heneralna prokuratura Ukrainy [Common reports of criminal offenses for the 2013-2017: General Prosecutor of Ukraine]. Retrieved from: http://www.gp.gov.ua/ ua/stat.html (accessed 10 June 2018)

Zakon Ukrainy «Pro innovatsiinu diialnist» [The Law of Ukraine «On innovation»]. Retrieved from: http://zakon5.rada.gov.ua/laws/show/40-15 (accessed 10 June 2018)

Zakon Ukrainy «Pro osnovy natsionalnoi bezpeky Ukrainy» [The Law of Ukraine «On National Security of Ukraine»]. Retrieved from: http://zakon1.rada.gov.ua/laws/show/964-15 (accessed 10 June 2018) 